\title{
Dynamism in Traditional Ecological Knowledge: Persistence and Change in the Use of Totora (Schoenoplectus californicus) for Subsistence in Huanchaco, Peru
}

\author{
Rossana Paredes $^{1^{*}}$ and Allison L. Hopkins ${ }^{1}$ \\ ${ }^{1}$ Department of Anthropology, Texas A\&M University, College Station, TX, USA. \\ *rossanaparedes88@tamu.edu
}

\begin{abstract}
Along the Peruvian north coast, many towns depend on fishing for subsistence. The adoption of technological innovations has facilitated the extraction of marine resources from the Pacific Ocean by Peruvian fishermen in recent years. However, some artisanal fishermen continue to rely on traditional ecological knowledge (TEK) to create sea vessels using botanical resources. This is the case of the fishing community of Huanchaco, a beachside town, where a reed locally known as totora (Schoenoplectus californicus) is cultivated in sunken gardens and is principally used to construct caballitos de totora, reed sea craft. This reed is also used for other purposes that benefit the fishing community economically. The objective of this article is to highlight the dynamic quality of TEK by describing the persistence and change in use of totora by the fishing community of Huanchaco. Participant observation techniques and individual interviews were conducted with 40 members of the fishing community. Results show that they are currently using totora for three different purposes: the construction of sea craft, which facilitates the catching of edible marine resources for subsistence and sale, and the sale of reed mats and souvenirs for additional income. Evidence from the recent past and the historical and pre-Hispanic periods suggests that some aspects of the technology of reed vessel construction have persisted whereas others have been modified. The addition of souvenirs and a reduction in mat production have also been identified. These changes in TEK highlight its dynamic quality, and are likely in response to economic and technological changes influenced by processes of globalization.
\end{abstract}

Received November 17, 2017

OPEN ठACCESS

Accepted March 2, 2018

DOI 10.14237/ebl.9.2.2018.1176

Keywords Peru, Traditional ecological knowledge, Totora, Sea craft, Mats, Souvenirs

Copyright (c) 2018 by the author(s); licensee Society of Ethnobiology. This is an open-access article distributed under the terms of the Creative Commons Attribution-NonCommercial 4.0 International Public License (https://creativecommons.org/licenses/by-nc/4.0), which permits non-commercial use, distribution, and reproduction in any medium, provided the original author and source are credited.

\section{Introduction}

A limited number of studies on traditional ecological knowledge (TEK) have assessed the ability of these knowledge systems to cope with social and environmental change (Athayde et al. 2017; ReyesGarcía et al. 2014). Generally, the focus on TEK change is related to globalization, which can lead to major lifestyle changes through widespread exposure to new technologies and cultural practices and modification of the natural environment. Historically, ethnobotanical studies have focused on how to capture the loss of TEK that was often assumed to result from globalization processes (Hanazaki et al. 2013), however, Gómez-Baggethun and Reyes-García (2013) argue that this perspective is shortsighted and that TEK should be studied as dynamic systems of knowledge that are able to cope with some degree of social change. The objective of this study is to highlight the dynamic quality of TEK by describing the persistence and change in use of totora reeds for various economic activities by the fishing community of Huanchaco, Peru.

In Peru, globalization has produced "hybrid cultures" (Burgos et al. 2003) resulting from the interaction of people from different cultures and with different identities. Hybrid cultures are characterized as maintaining some aspects of local traditions and knowledge while incorporating new practices. The neo-liberal economic reforms of the late 1980s through the 1990s have accelerated this process through promoting trade liberalization that favors exchange between local and foreign markets (Crabtree 
2002). The dynamic quality of TEK has been observed in northern Peru where healers and the public react to increasing access to a global market by experimenting with newly available remedies while maintaining their healing traditions (Bussmann 2013). Studies of the dynamic quality of TEK have primarily been carried out in Amazonian and Andean communities (Balslev et al. 2010; Paniagua-Zambrana et al. 2017; Pirker et al. 2012). However, along the Peruvian coast, some communities have also shown that they are able to adapt their TEK to changing socioeconomic conditions.

In coastal Peru, the diverse marine resources of the Pacific Ocean provide benefit to coastal communities. Due to the moderate to extremely high primary productivity $\left(150-300 \mathrm{gC} / \mathrm{m}^{2} / \mathrm{yr}\right)$ and the highly productive fisheries (accounting for 16\%-20\% of global fish captures) of the Humboldt Current (Miloslavich et al. 2011), the economic activities of coastal peoples in this area are primarily based on their relationship with the sea. The technological revolution has influenced the fishermen's traditions by motivating them to develop and adopt new fishing techniques and vessels through time. The large-scale fleet (with a hold capacity of more than $32.4 \mathrm{~m}^{3}$ per vessel) now dominates the fishing industry off the coast of Peru and is composed mainly of industrial pelagic purse seiners and coastal trawlers (FAO-UN 2010). These large boats have allowed fishermen to extract a variety of marine resources in much greater quantities in comparison to small and artisanal boats. However, these processes of delocalization (Pelto 1973) in the construction and use of specialized fishing vessels have not been adopted by fishermen in every coastal town. Some communities have developed economic systems where different types of boats, from traditional vessels to those constructed using the latest technology, are used in combination to increase the efficiency and productivity of fisheries.

On the Peruvian north coast, there are still communities where artisanal fishermen build sea craft using plants that grow locally, despite the extensive changes that have taken place in Latin America as the result of European colonization and the recent acceleration of globalization. This is the case of the town of Huanchaco, where the fishing community relies on TEK for the construction of reed vessels that are used to access edible resources from the sea. Apart from fishing, local inhabitants depend on other economic activities, including those using plants, to support their families. More specifically, totora reeds (Schoenoplectus californicus [C. A. Meyer] Soják), the most valuable botanical resource in the fishing community of Huanchaco, are used by fishermen to make caballitos de totora, a boat used in fishing. The construction of the caballitos de totora has been described by Rondón and colleagues (2003), and its importance in Peru and local management strategies has been discussed by Banack and colleagues (2004) previously. Totora reeds are also used in other economic activities, such as the creation of mats of different sizes that can be used as beds, rugs, windbreaks, roofs, and materials for housing construction (Heiser 1978). In addition, people who are no longer fishing devote most of their time to making tourist souvenirs from totora.

\section{Methods and Description of Study Region}

The study took place in Huanchaco, a beachside town with a population of 68,104 (INEI 2017) located in the La Libertad region of northern Peru (Figure 1). The coast of Peru is a sandy strip that lies between the Pacific Ocean and the Andes mountains. In spots, the coastal desert is crossed by rivers flowing from the highlands that provide irrigation to crops cultivated in the valleys and slash the sands with patches of green (Benson 2012). Around Huanchaco, both wild and cultivated botanical resources grow in habitats between the shoreline and inland territories (McTavish 2013). Huanchaco was chosen for the study because it is one of the few towns in Peru where totora reeds are still cultivated and used by people. Totora reeds grow in sunken gardens, locally known as wachaques, located $4 \mathrm{~km}$ north of Huanchaco in part of a protected reserve. Extended families own portions of that land where they cultivate and harvest totora reeds using a traditional process (see Banack et al. 2004). These families are part of the fishing community of Huanchaco, where a total of 30 fishermen currently perform fishing activities.

The traditional culture of Huanchaco dates back to pre-Hispanic times. During the Initial Period (1500 $-1200 \mathrm{BCE})$, the fishing community of Gramalote settled in Huanchaquito, a neighborhood of Huanchaco, and exploited marine resources while following a marine-oriented ideology (Prieto 2015). Then, Salinar (200 BCE - 200 CE), Gallinazo (200 BCE - $300 \mathrm{CE})$, Moche (100-700 CE), and Chimu (1000-1400 CE) peoples continued to inhabit and use the Huanchaco coastal port for daily embarkations (Anhuamán 2014). The traditional fishing systems and the domestication of plants, together, promoted the 

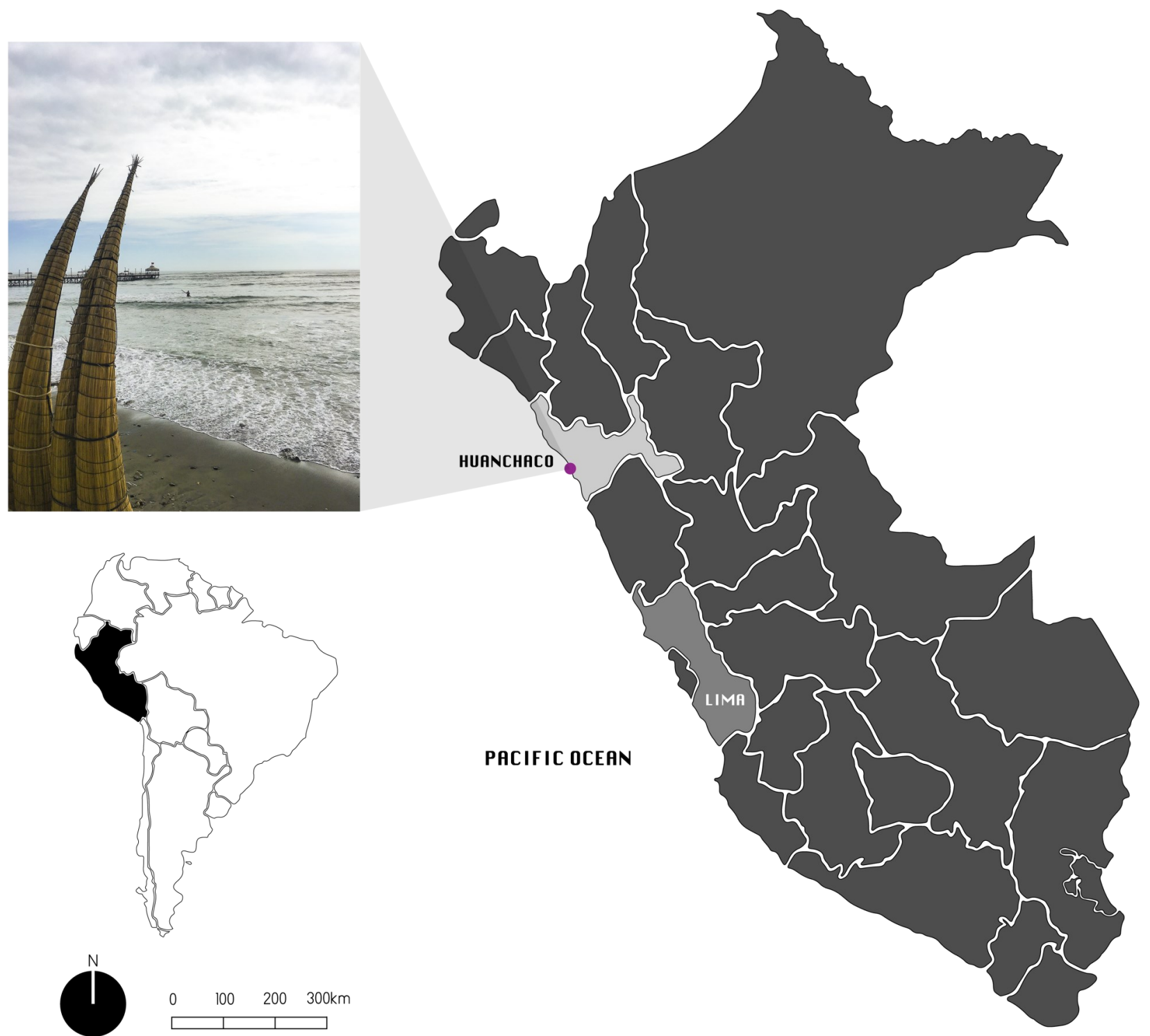

Figure 1 Location of Huanchaco in northern Peru.

rise of political and social complexity in coastal Peru (Sandweiss 2009) and resulted in a continuation of Huanchaco fishing activities during the Inca Empire and through the Spanish Conquest in 1572. During Colonial times, Huanchaco was an important port through which Spanish people and merchandise entered the region, serving as a catalyst for culture change. Technological innovations were introduced and pre-Hispanic sea vessels started to be displaced by occidental types within the fishing communities (Ortiz 2003).

Today Huanchaco is divided into urban and rural areas. In the urban areas, most jobs are administrative and/or associated with providing public and private services, whereas in the rural areas artisanal fishing and totora cultivation are the most common means of subsistence (Pulido 2010). The main economic activity in Huanchaco is tourism, primarily due to its designation as a World Surfing Reserve in 2013 (Save the Waves 2015). People from around the world visit the town demanding services and facilities that meet international standards. As the tourism industry has grown in the region, it has provided increasing job opportunities that have attracted former fishermen and/or their sons. Also, unsustainable fishing practices such as overfishing and sea contamination 


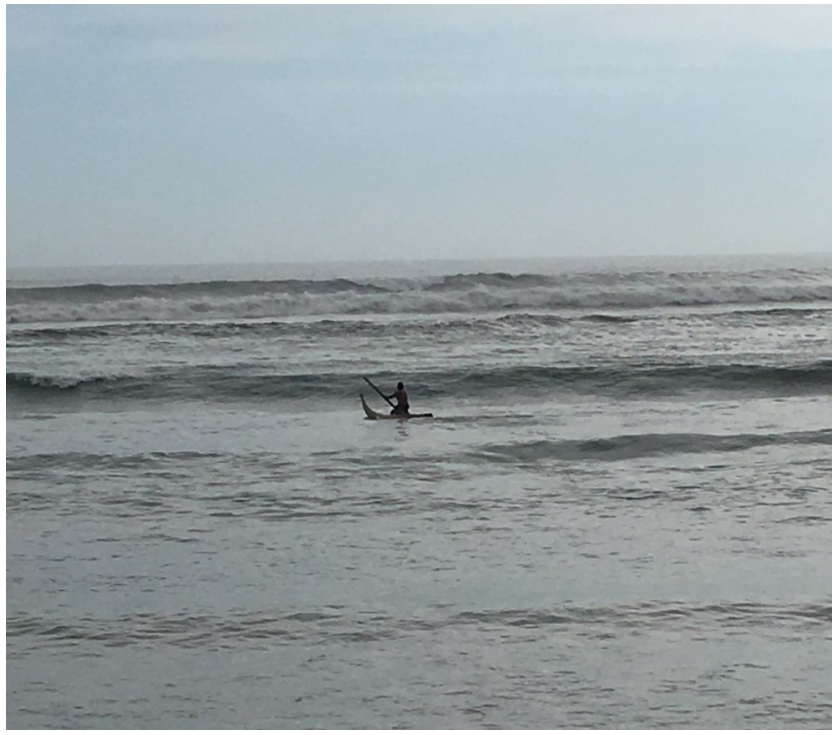

Figure 2 A man starting a fishing routine.

(Veneros 2008) have affected fishing performance and catchment, and forced some people to look for alternative economic activities to support their families. Additionally, the political system has not always worked in favor of the fishing community. Some of the previous mayors allowed for the expansion of the urban area to meet the tourism demand which reduced the availability of land for the cultivation of crops and totora by fishermen (Pulido 2010). Despite these changes and the reduction in fishermen as a result, approximately 30 families continue to fish using traditional vessels as their primary livelihood strategy.

In the summer of 2017, we conducted unstructured interviews (IRB 2017-0033M) and utilized participant observation techniques (Spradley 1980) with 20 men and 2000 women over the age of 18 to become more familiar with the use of totora among the fishing community of Huanchaco. People were asked how they used totora reeds in their daily subsistence activities. The information provided by the informants was grouped according to each totora use.

\section{Results}

The fishing community uses totora reeds for three different economic purposes: the construction of caballitos de totora fishing boats, souvenirs, and mats. There is a clear gender division of labor in the growing and processing of totora in Huanchaco for the production of these three different goods. Men oversee the cultivation and harvest of totora, the construction of caballitos, and the creation of souvenirs, while women weave totora mats. The reason for this gender differentiation, according to the fishermen, is that women are not strong enough to cut, clean, and carry large amounts of reeds to construct the heavy and long caballitos de totora. Women know where the sunken gardens are located but it is rare to see a woman around the protected reserve, especially taking care of the reeds that belong to their families. If women need totora reeds for the construction of mats or other activities, then they ask their spouses or male relatives for some or buy them at the local market. None of the participants have ever seen a woman making her own caballito; however, women sometimes assist with the process through acquiring construction supplies such as ropes and buoyant materials in the market. Additionally, men have not been observed weaving mats.

\section{Totora Reed Vessels}

The caballitos de totora are used as vessels for fishing in the Pacific Ocean (Figure 2). The construction process takes at least two hours with two men working together and is divided into three stages. The fishermen take their time in constructing the vessel because they believe that the quality of the vessel can have a direct impact on their fishing performance. First, they separate the totora reeds into four bundles, two made of first-class reeds, $3 \mathrm{~m}$ long, and the other two of the second-class reeds, $2 \mathrm{~m}$ long. After this, they place a square piece of Styrofoam in each bundle and tie them with a nylon rope, generating two longer "mother" bundles and two shorter "son" bundles. Next, each son bundle is connected to each mother bundle by tightly wrapping each mother bundle in a spiral fashion (one clockwise and the other counter clockwise) with a nylon rope, which forms a pit where the son bundle is placed (Figure 3a). Finally, the two mother-son bundles are joined with a double twist nylon rope, making several knots along the caballito length and creating an upturned bow (Figure $3 \mathrm{~b}$ ). The caballito is then ready to sail (Figure 3c). The reed vessel lasts for approximately a month and then a new one needs to be fashioned.

\section{Totora Souvenirs}

Elderly men and retired fishermen make souvenirs that they sell to the great number of tourists that visit Huanchaco each year. Artisans buy totora reeds and make different kinds of souvenirs such as earrings, key chains, refrigerator magnets, photo frames, and other 


\section{(fi) Ethinobiolocy Letters \\ Research Communications}

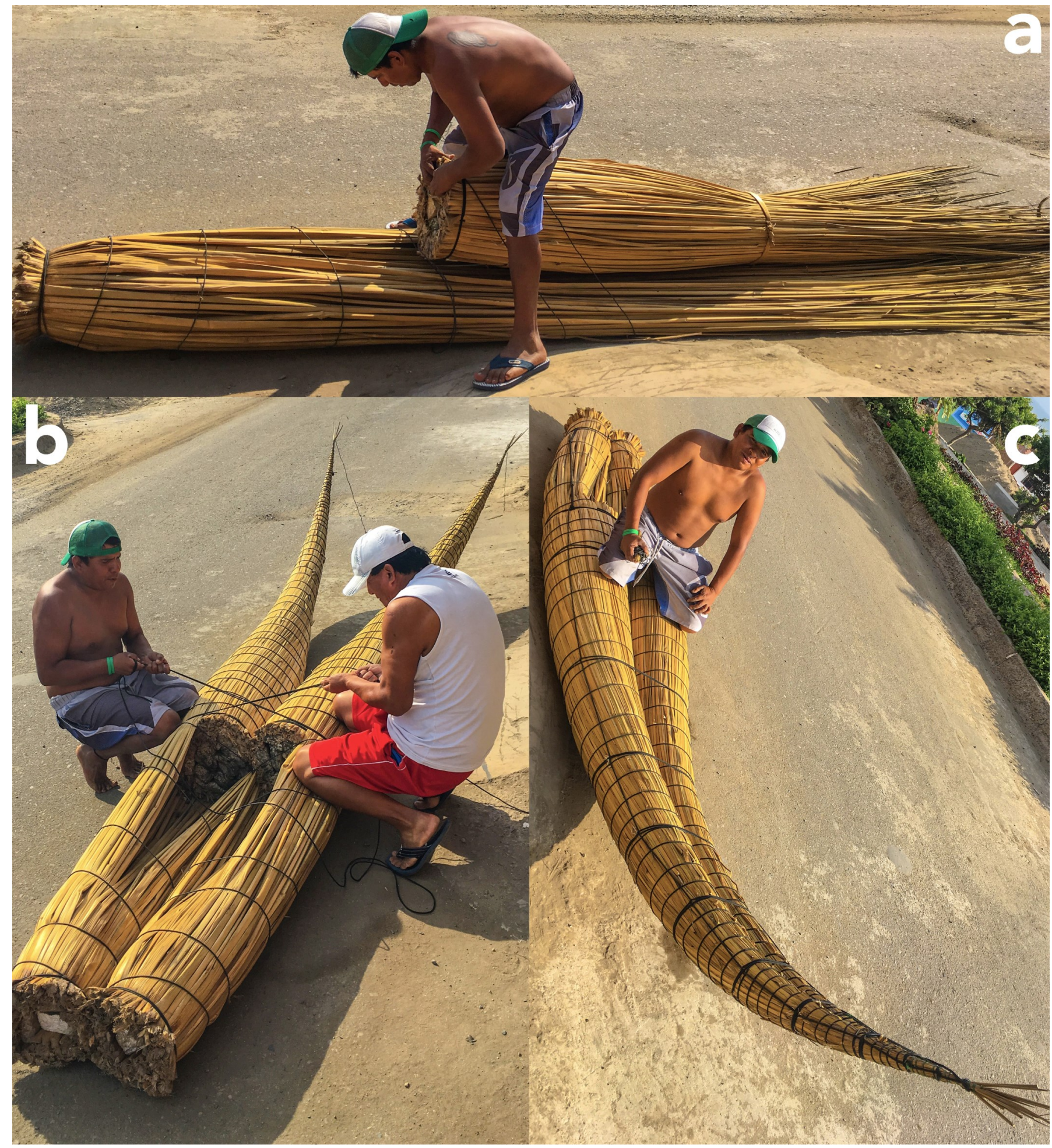

Figure 3 Fishermen constructing a caballito de totora. A Son bundle is connected to mother bundle. B The two mother-son bundles are joined with a nylon rope. $C$ The caballito is ready to sail. 


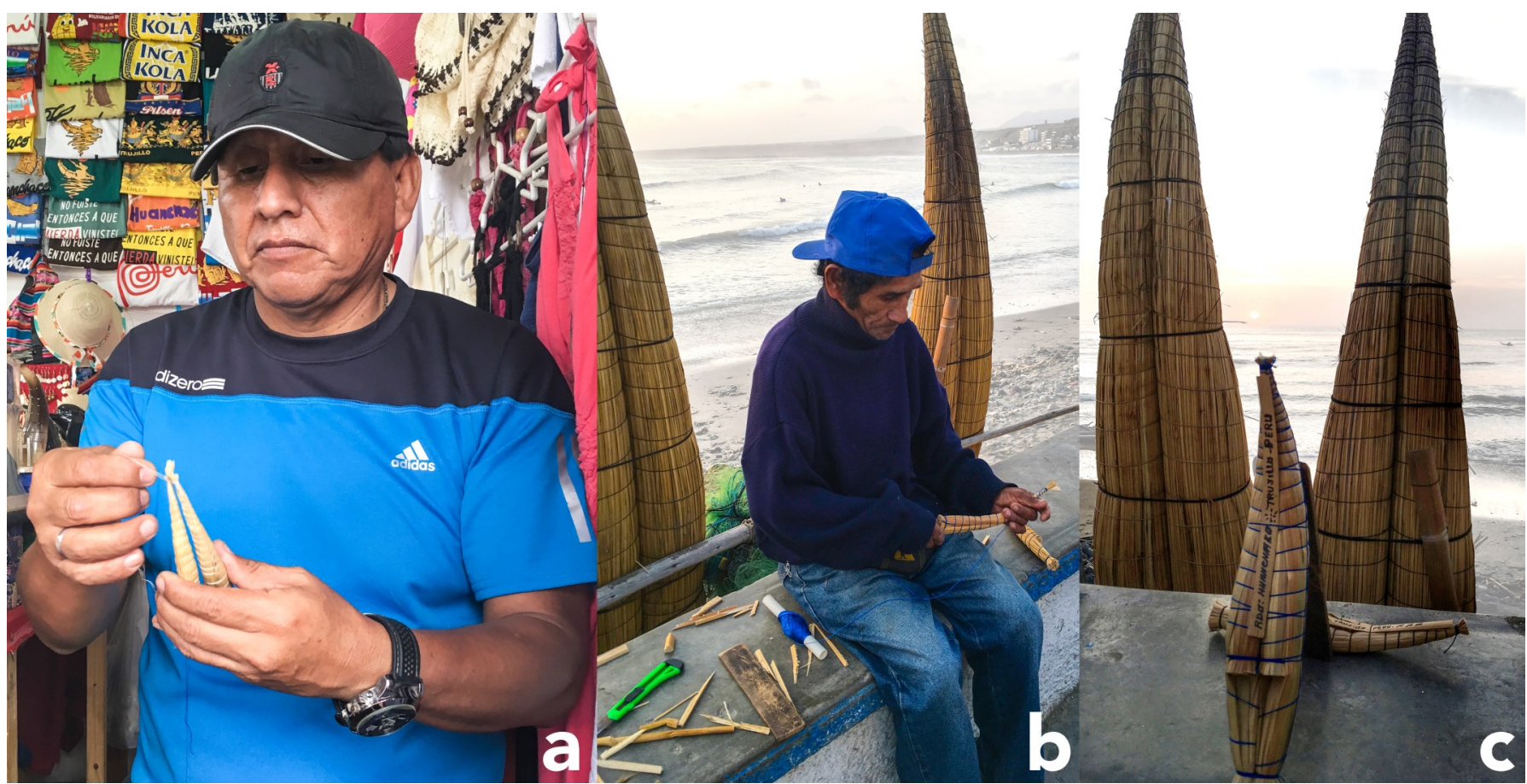

Figure 4 Artisans creating a caballito souvenir. 4a: Reed bundles are connected in the same fashion as the full size caballito. 4b: Bundles are finely sharped, tightly wrapped and connected using a nylon rope. 4c: A "Huanchaco-Trujillo-Peru" label is attached under the nylon strips.

ornaments that they sell in the artisan market. The most popular souvenir is a little version of the caballito, an ornament that can be used for decoration in a home or office (Figure 4). The construction process is a faster and simpler version of the process for making the full size caballitos. Four bundles of short totora reeds, two mothers of $15-20 \mathrm{~cm}$ long reeds and two sons of $5 \mathrm{~cm}$ long reeds, are needed to make a little caballito. The bundles are connected in the same fashion as the full size caballito de totora (Figure 4a). Once each son bundle is placed inside each mother bundle, the artisans finely sharpen the reeds on the end using a razor to get the upturned bow like the full-sized version. Then, each piece is tightly wrapped in a spiral fashion in both clockwise and counter-clockwise directions to reinforce the caballito shape. Finally, both bundles are connected using a fine blue or black nylon rope by making knots every centimeter (Figure 4b). The artisans write on a little piece of totora "Huanchaco - Trujillo - Peru" and attach it under the nylon strips (Figure 4c). It takes about 15 minutes for each artisan to make a caballito souvenir. The artisans charge between 5 and 50 soles (between 2 and 16 US dollars) for their products depending on the type and size.

\section{Totora as Mats}

Totora is the raw material in the weaving of mats, which are then crafted into handheld fans, artisanal mattresses, and material for house construction, especially roofs. Currently, there is just one woman that makes and sells mats in the town. She is now over 60 years old and she has been making mats since she was young. Therefore, her name is well known around the town, and everyone that needs a high quality and well-crafted mat goes to see her. She buys the totora reeds and shapes them according to her clients' preferences. Then, she starts twining the totora reeds by interweaving a cotton cord at intervals of $30 \mathrm{~cm}$ until the desired length is reached (Figure 5). It takes all day for her to finish one small mattress (twin size). Her perception is that this is a long time and is due to her advanced age. She can take up to five days to create a mat, depending on the purpose, the size of the mat, and the number of orders she receives. She charges an average of 30 soles (less than ten US dollars) for a $3 \mathrm{~m} \mathrm{x} 4 \mathrm{~m}$ mat.

\section{Discussion}

The dynamic quality of TEK in response to economic and technological changes (Gómez-Baggethun and Reyes-García 2013) is observed in the fishing 


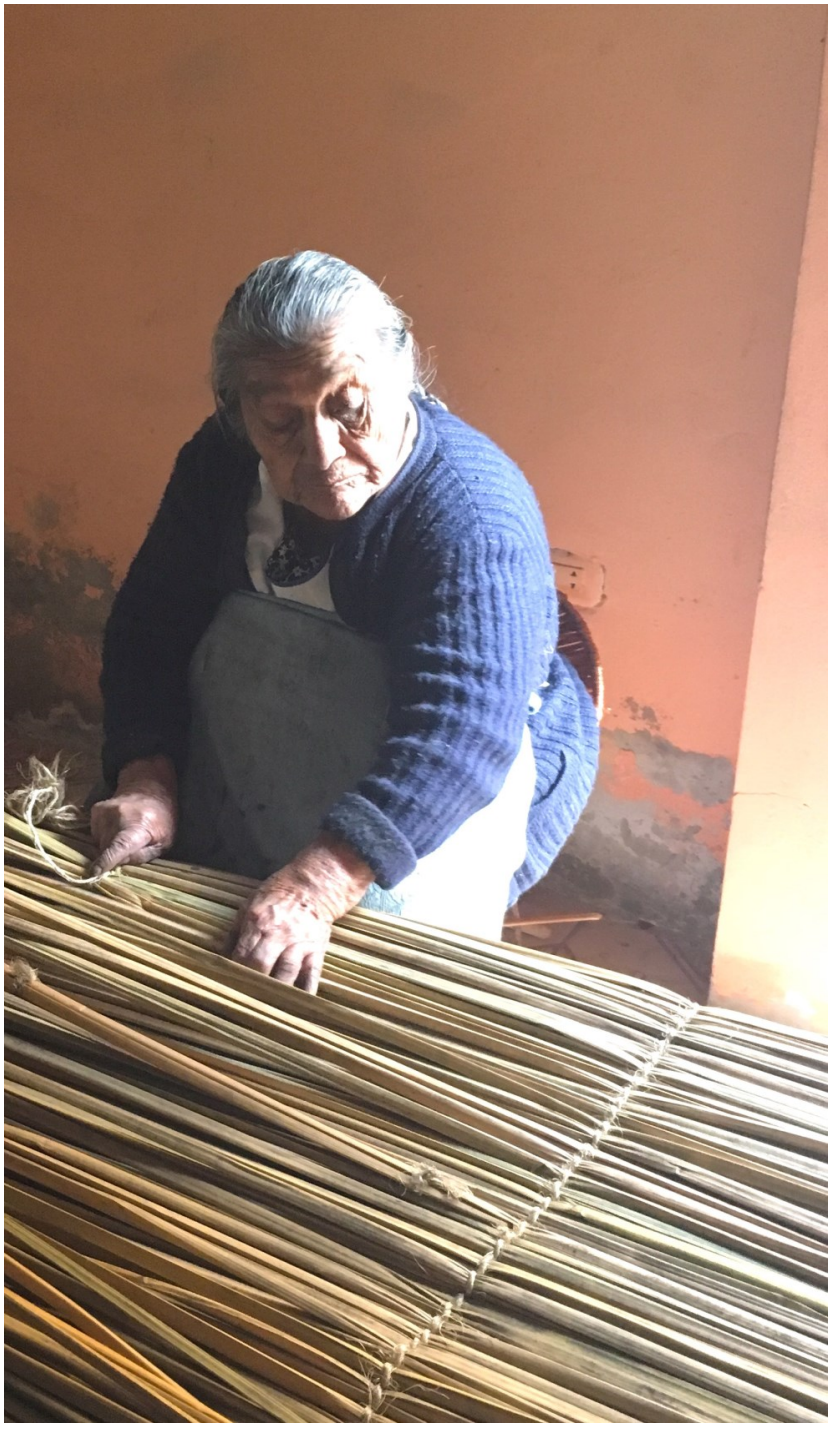

Figure 5 A local woman weaving a mat.

community of Huanchaco. TEK related to totora use for subsistence has persisted and changed in response to the growing tourism industry, the reduction in availability of reeds, and the increasing accessibility of industrially produced materials that can be used in boat and house construction. Totora continues to play an important role in economic strategies that support the subsistence of the fishing community in Huanchaco. Fishing community members have a direct relationship with totora reeds, understanding and processing the plant in different ways according to their gender roles.

TEK related to totora uses has persisted through time despite the changes that have taken place as the result of colonization and globalization. Population growth and government prioritization of tourist activities have reduced the availability of arable land; however, the remaining fishermen have claimed an area exclusively for totora cultivation. Also, colonization introduced the use of western sea craft but the local people developed a fishing system where different types of sea craft, industrial and artisanal, can be used (Prieto 2016). The archaeological record provides evidence of continuity in aspects of the construction and use of caballitos de totora since preHispanic times. Caballitos de totora were considered the principal means of water transportation for coastal people before the Spanish Conquest (Lothrop 1932). The pottery from the Chavin (850-300 BCE), Moche (100-700 CE), and Chimu (1000-1400 CE) cultures portray daily activities of people and gods and includes the use of caballitos de totora for transit as well as for fishing within several coastal sites (Baessler 1906; Benson 2012; Rostworowski 1981). Larger caballitos represented in the Moche iconography of San Jose de Moro are occupied by a female figure, the Priestess, and male figures with supernatural attributes (Castillo 2003; McClelland et al. 2007). In addition, the paleoethnobotanical record of the Gramalote site (1500-1200 BCE) suggests the presence and perhaps cultivation of totora in the Huanchaco surroundings. Among these totora remains recovered are a $10-\mathrm{cm}$ fragment of a small caballito de totora end showing totora reeds tied with a cotton rope (Prieto 2015); pollen grains identified in sediment samples from two human occupations (Paredes 2018); phytoliths identified from sediment samples and artifacts recovered from three human occupations (Villanueva 2014); and fragments of cords, baskets, and mats made of totora and remains of the reed itself recovered during the last period of field excavations of the site (Prieto 2015).

Totora reeds grow in humid marsh-like habitats, such as those found along the Peruvian coast (Fernández and Rodríguez 2007). Coastal peoples can cultivate and use totora in their daily activities, especially as a means of transportation that allows fishermen to interact with the resource-rich sea. The use of totora vessels in Peru is favored by the coastal relief with numerous shallow coves that are not appropriate for anchoring large and heavy boats (Prieto 2016). Currently, totora reeds are used exclusively in seven fishing communities in northern Peru: Uripe, Huanchaco, Puemape, Cherrepe, Puerto Eten, Santa Rosa, and Pimentel, which are located within the La Libertad and Lambayeque regions (Prieto 2016). In the recent past, totora vessels were also used in coves along the central and southern 
Peruvian coast, particularly along the Chincha, Cañete, Asia, Mala, Chilca, Lurin, and Chillon valleys (Edwards 1965; Ortiz 1990; Rostworowski 2004); however, people from those regions have replaced totora reed craft with boats constructed from more durable materials.

The TEK related to caballitos is considered an important part of the Huanchaco cultural heritage and, in an effort to maintain it, children start interacting with reeds in the early years at school. They learn how to make small replicas of caballitos de totora as an art project. In addition, parents teach their children to sail using reed vessels, and when they become adolescents they start learning the construction process of the full sized caballito. Rondón and colleagues (2003) have described in detail the process involved in the caballito construction and our observations indicate that the construction process has not changed in the intervening years. As a result, TEK related to totora use in Huanchaco continues to be transmitted from older to younger generations through observation as an embedded part of culture, much like McMillen and colleagues (2017) found in Hawai'i for knowledge storage and transmission on subsistence livelihood practices.

On the other hand, TEK on totora use has changed in response to new economic and technological conditions, highlighting the dynamic aspect of TEK. Although cultivation areas are limited, thus reducing the supply of totora, fishermen have not stopped constructing caballitos; instead they have replaced the reeds used as filling with Styrofoam. The result is a more durable and buoyant caballito. In addition, nylon ropes have replaced the cabuya (Furcraea andina Trel.) ropes that fishermen previously used to tie the bundles of totora (Rondón et al. 2003). The main reasons for that change is that nylon ropes are cheaper and more readily available than cabuya ropes. Today, no cabuya plants are observed in the nearby habitats of Huanchaco and the younger generation of fishermen have never heard of the plant. The archaeological record provides evidence of the use of cabuya in the creation of ropes and cordage since $1500 \mathrm{BCE}$, as identified in the macrobotanical record of the Gramalote site (Prieto 2015). Therefore, TEK on totora use has changed through modifications in the construction process of the caballitos favored by the availability of new construction materials in the local market as the result of globalization.

Additionally, in search for extra income, fishermen have generated new TEK of totora in that they now construct and sell souvenirs. The addition of souvenirs into their economic strategies compensates for declining fishing profits. The integration of TEK into the tourist economy is also observed in northwest Argentina where individual and community knowledge of textile craft production has adapted to new market demands (Lambaré et al. 2011). In Huanchaco, the fishing community now supplement their waning fishing profits by responding to the demand of tourists for local and innovative souvenirs that represent the Huanchaco culture. The souvenirs represent the fishing activities, which are an important part of Huanchaco identity, and provide evidence of the dynamic responses of TEK to change within subsistence-based and place-based communities, as was observed in the adaptation of TEK related to forecasting in the Hawai'ian Islands (McMillen et al. 2017).

Finally, there is some evidence of loss of totora TEK due to new construction technologies and changes in the economy of Huanchaco. Increased access to technologically advanced housing materials resulting from globalization has resulted in people replacing the use of totora mats with inorganic and more durable materials such as concrete, wood, and plastic. Also, women prefer to perform other economic activities as they perceive that mat construction does not produce a sufficient income in Huanchaco's current economy. As a result, the knowledge of mat construction and use in building will likely not persist once the sole keeper of that knowledge passes on.

\section{Conclusion}

The fishing community of Huanchaco continues to work directly with totora reeds for their subsistence activities. Totora has been used since pre-Hispanic times in the construction of the caballito de totora and the creation of mats, and more recently in the development of souvenirs. Totora TEK has economic and cultural value for Huanchaco people as the reeds generate income and represent a traditional building material emblematic of the northern region of Peru. To cope with economic and technological changes, the fishing community of Huanchaco has maintained some aspects of totora TEK while changing other aspects. Specifically, the techniques of caballito construction have persisted across generations, while some of the construction materials have changed; the use of totora in making souvenirs was developed; and a 
reduction in mat production has occurred. Thus, totora use in Huanchaco reflects the dynamic quality of TEK in response to social changes influenced by processes of globalization.

\section{Acknowledgments}

This work was supported by a grant from the Anthropology Department at Texas A\&M University. We would like to express our gratitude to the fishing community of Huanchaco for their participation in this study. We thank Luis Alexander Urcia, an honored member of the fishing community, for his help and hospitality in the field. Finally, we wish to express our gratitude to Dr. Vaughn Bryant for his comments and suggestions during the preparation of this manuscript.

\section{Declarations}

Permissions: Permission for this study was granted by the IRB (2017-0033M) of Texas A\&M University and the fishing community of Huanchaco. All participants provided their informed consent.

Sources of funding: This study was funded by a grant from the Anthropology Department at Texas A\&M University.

Conflicts of Interest: None declared.

\section{References Cited}

Anhuamán, P. 2014. Huanchaco: Cultura Viva Muchik-

Chimor de la Costa Norte del Perú. Editorial

Universitaria de la Universidad Nacional de Trujillo, Trujillo, Peru.

Athayde, S., M. Schmink, J. Silva-Lugo, and M. Heckenberger. 2017. The Same, but Different: Indigenous Knowledge Retention, Erosion, and Innovation in the Brazilian Amazon. Human Ecology 45:533-544. DOI:10.1007/s10745-017-9919 -0 .

Baessler, A. 1906. Altperuanische Metallgeräte: Nach Seinen Sammlungen. Georg Reimer, Berlin.

Balslev, H., T. R. Knudsen, A. Byg, M. Kronborg, and C. Grandez. 2010. Traditional Knowledge, Use, and Management of Aphandra natalia (Arecaceae) in Amazonian Peru. Economic Botany 64:55-67.

DOI:10.1007/s12231-009-9105-4.

Banack, S. A., X. J. Rondón, and W. DiazHuamanchumo. 2004. Indigenous Cultivation and Conservation of Totora (Schoenoplectus californicus, Cyperaceae) in Peru. Economic Botany 58:11-20.
Benson, E. P. 2012. The Worlds of the Moche on the North Coast of Peru. University of Texas Press, Austin, TX.

Burgos Y., J. Coasaca, and V. Valcárcel. 2003. La Globalización: Análisis e Impacto en el Perú. Producción y Gestión 6:20-26. DOI:10.15381/ idata.v6i2.6023.

Bussmann, R. W. 2013. The Globalization of Traditional Medicine in Northern Peru: From Shamanism to Molecules. Evidence-Based Complementary and Alternative Medicine 291903:1-46. DOI:10.1155/2013/291903.

Castillo, L. J. 2003. Los Últimos Mochicas de Jequetepeque. In Moche hacia el Final del Milenio, edited by S. Uceda and E. Mujica, vol. 2, pp. 65123. Universidad Nacional de Trujillo y PUCP Fondo Editorial, Lima.

Crabtree, J. 2002. The Impact of Neo-Liberal Economics on Peruvian Peasant Agriculture in the 1990s. The Journal of Peasant Studies 29:131-161. DOI:10.1080/03066150412331311049.

Edwards, C. 1965. Aboriginal Watercraft on the Pacific Coast of South America. University of California, Berkeley, CA.

Fernández, A. M., and E. F. Rodríguez. 2007. Etnobotánica del Perú Pre-bispano. Ediciones Herbarium Truxillense (HUT), Universidad Nacional de Trujillo, Trujillo, Peru.

Food and Agriculture Organization of the United Nations (FAO-UN). 2010. Fishery and Aquaculture Country Profiles. The Republic of Peru [web page]. Available at: http://www.fao.org/fishery/facp/ PER/en. Accessed on July 31, 2017.

Gómez-Baggethun, E., and V. Reyes-García. 2013. Reinterpreting Change in Traditional Ecological Knowledge. Human Ecology 4:643-647. DOI:10.1007/s10745-013-9577-9.

Hanazaki, N., D. F. Herbst, M. S. Marques, and I. Vandebroek, I. 2013. Evidence of the Shifting Baseline Syndrome in Ethnobotanical Research. Journal of Ethnobiology and Ethnomedicine 9:75. DOI:10.1186/1746-4269-9-75.

Heiser, C. 1978. The Totora (Scirpus californicus) in Ecuador and Peru. Economic Botany 32:222-236. DOI:10.1007/bf02864698.

Instituto Nacional de Estadística e Informática (INEI). Perú en Cifras: La Libertad [web page]. Available at: http://www.inei.gob.pe. Accessed on November 10, 2017. 
Lambaré, D. A., N. I. Hilgert, and R. S. Ramos. 2011. Dyeing Plants and Knowledge Transfer in the Yungas Communities of Northwest Argentina. Economic Botany 65:315-328. DOI:10.1007/s12231011-9169-9.

Lothrop, S. J. 1932. Aboriginal Navigation off the West Coast of South America. Journal of the Royal Anthropological Institute of Great Britain and Ireland 62:229-256. DOI:10.2307/2843956.

McClelland, D., D. McClelland, and C. Donnan. 2007. Moche Fineline Painting from San Jose de Moro. The Cotsen Institute of Archaeology Press, Los Angeles.

McMillen, H., T. Ticktin, and H. Springer. 2017. The Future is Behind Us: Traditional Ecological Knowledge and Resilience over Time on Hawai $i$ Island. Regional Environmental Change 17:579-592. DOI:10.1007/s10113-016-1032-1.

McTavish, R. 2013. Faunal Subsistence Strategies among Initial Period Coastal Fishers at the Gramalote Site in the Moche Valley of Peru. Unpublished Master's Thesis, Department of Anthropology, University of Wisconsin-Milwaukee, Milwaukee, WI.

Miloslavich, P., E. Klein, J. M. Díaz, C. E. Hernández, G. Bigatti, L. Campos, F. Artigas, J. Castillo, P. E. Penchaszadeh, P. E. Neill, A. Carranza, M. V. Retana, J. M. Díaz de Astarloa, M. Lewis, P. Yorio, M. L. Piriz, D. Rodríguez, Y. Yoneshigue-Valentin, L. Gamboa, and A. Martín. 2011. Marine Biodiversity in the Atlantic and Pacific Coasts of South America: Knowledge and Gaps. PLOS ONE 6:1-43. DOI:10.1371/journal.pone.0014631.

Ortiz, J. 1990. Embarcaciones Aborígenes en el Área Andina. Historia y Cultura 20:49-79.

Ortiz, J. 2003. Navegación en la Zona Sur Andina. Derroteros de la Mar del Sur 11:123-135.

Paniagua-Zambrana N., R. W. Bussmann, and M. J. Macía. 2017. The Socioeconomic Context of the Use of Euterpe precatoria Mart. and E. oleracea Mart. in Bolivia and Peru. Journal of Ethnobiology and Ethnomedicine 13:32. DOI:10.1186/s13002-017-0160 $-0$.

Paredes, R. 2018. Paleoethnobotany of the Early Initial Period of Gramalote in Northern Peru. Economic Botany 72:94-106. DOI:10.1007/s12231018-9402-x.

Pelto, P. J. 1973. The Snowmobile Revolution: Technology and Social Change in the Arctic. Cummings Publishing
Company, Menlo Park, CA.

Pirker, H., R. Haselmair, E. Kuhn, C. Schunko, and C. R. Vogl. 2012. Transformation of Traditional Knowledge of Medicinal Plants: The Case of Tyroleans (Austria) who Migrated to Australia, Brazil and Peru. Journal of Ethnobiology and Ethnomedicine 8:44. DOI:10.1186/1746-4269-8-44.

Prieto, G. 2015. Gramalote: Domestic Life, Economy and Ritual Practices of a Prehispanic Maritime Community. Unpublished Doctoral Dissertation, Department of Anthropology, Yale University, New Haven, CT.

Prieto, G. 2016. Balsas de Totora en la Costa Norte del Perú: Una Aproximación Etnográfica y Arqueológica. Quingnam 2:139-186.

Pulido, V. 2010. El Balsar de Huanchaco. Report 6.3. Ramsar, Trujillo, Peru.

Reyes-García, V., J. Paneque-Gálvez, A. C. Luz, M. Gueze, M. J. Macía, M. Orta-Martínez, and J. Pino. 2014. Cultural Change and Traditional Ecological Knowledge: An Empirical Analysis from the Tsimane' in the Bolivian Amazon. Human Organization 73:162-173. DOI:10.17730/ humo.73.2.31nl363qgr30n017.

Rondón, X. J., S. A. Banack, and W. DiazHuamanchumo. 2003. Ethnobotanical Investigation of Caballitos (Schoenoplectus californicus: Cyperaceae) in Huanchaco, Peru. Economic Botany 57:35-47. DOI:10.1663/0013-0001(2003)057[0035:eiocsc] 2.0.co;2.

Rostworowski, M. 1981. Recursos Naturales Renovables y Pesca, Siglos XVI y XVII. Instituto de Estudios Peruanos, Lima, Peru.

Rostworowski, M. 2004. Costa Peruana Prehispánica. Instituto de Estudios Peruanos, Lima, Peru.

Sandweiss, D. H. 2009. Early Fishing and Inland monuments: Challenging the Maritime Foundations of Andean Civilization? In Andean Civilization: $A$ Tribute to Michael E. Moseley, edited by J. Marcus and P. R. Williams, pp. 39-54. The Cotsen Institute of Archaeology Press, Los Angeles.

Save the Waves. 2015. World Surfing Reserves [web page]. Available at: http://www.savethewaves.org. Accessed on August 03, 2017.

Spradley, J. P. 1980. Participant Observation. Harcourt Brace Jovanovich, Fort Worth, TX. 
Veneros, B. 2008. Caracterización de las Bases Biológicas-pesqueras para el Manejo Sustentable de los Principales Recursos que Soportan la Pesca Artesanal en la Zona Costera de la Región La Libertad, Perú. Programa de Doctorado en Ciencias Biológicas, Universidad Nacional de Trujillo, Trujillo, Peru.
Villanueva, F. 2014. Reconstrucción Paleoambiental del Sitio Arqueológico Pampas Gramalote Basada en Microrestos (La Libertad- Perú). Facultad de Ciencias Naturales y Matemáticas, Universidad Nacional Federico Villarreal, Lima, Peru. 